\title{
Forum Konsultasi Publik : Aktivis Masyarakat Sipil atau Klient Penguasa
}

\section{Community Consultations: Active Citizenship or Clientelism?}

\author{
Rutiana Dwi Wahyunengseh \\ Program Studi Ilmu Administrasi Negara Fakultas Ilmu Sosial dan Politik, \\ Universitas Sebelas Maret \\ rutiana.uns@gmail.com
}

\begin{abstract}
Abstrak
Forum Konsultasi Publik adalah bagian dari Musrenbang (Konsultasi Masyarakat Tahunan tentang Perencanaan Pembangunan) yang diintervensi sebagai bagian dari fase siklus perencanaan penganggaran daerah. Prosesnya dirancang untuk berorientasi pada pengambilan keputusan perencanaan pembangunan dengan format yang demokratis dan partisipatif. Dilihat dari dimensi akuntabilitas sosial, apakah mereka yang terlibat benar-benar anggota aktif atau klien? Artikel ini bertujuan untuk menganalisis fenomena perangkap "klienkomunitas aktif", karena perannya penting untuk kualitas dan output prosesnya. Hasil beberapa studi kasus di Kota Surakarta dan Magelang menunjukkan bahwa konsep komunitas aktif memiliki makna yang berbeda dilihat dari forum dan konteks fungsi akuntabilitas sosial. Pemerintah mengundang para peserta yang dianggap aktif berdasarkan penilaian birokrat. Atas nama forum yang lebih efisien, ada kooperasi forum melalui instruksi teknis pada organisasi forum. Akibatnya, pada dasarnya konsultasi publik membuat dialog semu untuk membuat keputusan secara akuntabel. Itu karena peserta aktif yang terlibat sebenarnya adalah klien yang dikooptasi sesuai dengan prosedur pemerintah. Kesimpulannya adalah bahwa lingkungan budaya formalitas birokrat dan kebiasaan komodifikasi dalam masyarakat menghasilkan patologi yang mengaburkan makna "komunitas aktif" terhadap "klien aktif".
\end{abstract}

\section{Kata kunci: partisipatif, kewarganegaraan, akuntabilitas sosial, Patologi}

\begin{abstract}
Abstrack
Public Consultation Forum is part of Musrenbang (Annually Community Consultations on Development Planning) which is intervened as a part of local budgeting planning cycle phase. Its process is designed to be oriented on development planning decision making with democratic and participatory format. Viewed from social accountability dimension, are those involved actually active members or clientilist? This article aimed to analyze the "active client-community" phenomenon pitfall, because its role is important to its process quality and output. The result of a multiple case study on Surakarta and Magelang Cities indicated that the concept of active community has different meaning viewed from forum and context of
\end{abstract}


social accountability function. The government invited the participants considered as active according to bureaucrat assessment. On the behalf of more efficient forum, there was forum cooptation through technical instruction on forum organization. As a result, essentially public consultation made a quasi-dialog to make decision accountably. It was because the active participants involved were actually the coopted clients corresponding to government procedure. The conclusion was that formality cultural environment of bureaucrat and comodification habit within society generated pathology obscuring the meaning of "active community" against "active clientilist".

\section{Keyword: participatory, citizenship, social accountability, Pathology}

\section{A. Pendahuluan}

Konsultasi publik yang dimaksud dalam artikel ini musyawarah pembangunan, dimana hasilnya akan menjadi bahan pengambilan keputusan penyusunan Anggaran Pendapatan dan Belanja Daerah (APBD). Prosesnya didesain berorientasi pada pembuatan keputusan rencana pembangunan dengan format demokratis dan memuat unsur partisipasi dari kelompok masyarakat yang disebut sebagai aktivis (active citizen).

Novelty dari artikel ini adalah mempertanyakan originalistas perwakilan aktivis yang berpartisipasi. Ditinjau dari dimensi akuntabilitas sosial, benarkah mereka yang terlibat adalah warga yang aktif, atau justru klientilis aktif? Artikel ini bertujuan mengupas jebakan fenomena "masyarakat aktif", karena posisi partisipan penting bagi kualitas proses dan kualitas keluarannya. Kebaruan) yang diungkapkan dalam artikel ini adalah ditemukan preposisi bahwa produk proses demokratis tidak selalu berkontribusi penguatan elemen nilai demokratis dikarenakan adanya jebakan patologi. Penelitian ini menemukan bahwa terjadinya jebakan patologi disebabkan adanya dua faktor. Pertama, cacat bawaan dari budaya yang menjadi fondasi diselenggarakannya proses mekanisme demokrasi. Kedua, budaya yang membentuk perilaku aktor yang terlibat di dalam proses demokrasi tersebut.

\section{B. Kerangka Literatur}

Konsep warga yang aktif (active citizenship) dalam akuntabilitas sosial (social accountability) menurut Clarke and Missingham (2009): "Active citizenship means people getting involved in their local communities and democracy at all levels, from towns to cities to nationwide activity, from small local isues until 
national isues." Konsep warga yang aktif merepresentasikan tiga domain isu yaitu: (a) partisipasi dari bawah; (b) pembangunan berbasis hak dasar warga (right based development); (c) pengakuan pentingnya peran pemerintah merespon warga dengan baik dan mendukung pembangunan yang berpihak warga (citizen), terutama pemenuhan hak dasar warga terpinggirkan.

Secara normatif, warga yang aktif digambarkan sebagai kunci utama perkembangan pembangunan berkelanjutan secara partisipatif, karena mereka mampu membangun posisi tawar dengan pemerintah dan agen publik lain yang terlibat dalam isu komunitas untuk dalam proses pembuatan keputusan pembangunan di area di mana mereka terkena dampaknya. Akibatnya, keputusan yang diambil akan berdampak menguntungkan publik secara luas dan meningkatkan kepercayaan publik pada kebijakan pembangunan yang berkelanjutan. Secara normatif, active citizen berperan (i) mewakili kemunitas menyuarakan pilihan prioritas kebutuhan pembangunannya; (ii) memonitor keadilan pelayanan publik di grass roots level, (iii) menguatkan partisipasi lokal di dalam proses pemerintahan, tidak hanya sekedar mengikuti pemilihan umum. Pelibatan publik secara langsung di dalam pembuatan keputusan disebut juga sebagai citizen governance.

Citizen memiliki beberapa cara mempengaruhi pebuatan keputusuan publik yang dibuat oleh birokrat dan politisi yang mengatasnamakan kepentingan mereka. Cara itu bervariasi mulai dari tindakan demokratis yang tradisional, seperti pemilihan umum, membuat petisi dan lobi (lobbying), hingga cara yang lebih informal, misalnya konsultasi publik, menyatakan komplain, dan pembuatan keputusan berbasis komunitas (Fung, 2006). Dalam democratic governance, melekat asumsi dasar demokrasi yang bertalian erat dengan power sharing, yaitu keseimbangan kekuasaan antara negara dengan pelibatan masyarakat sipil. Pelibatan active citizen mengawasi pejabat politik atau birokrasi dalam isu kebijakan, proses pembuatan kebijakan, atau pelaksanaan fungsi pelayanan adalah salah satu bentuk praktik demokrasi (Malena, et.al., 2004), sebagai bagian dari democratic governance jika dikaitkan 
dengan konsep keseimbangan masyarakat sipil dan negara (power sharing).

Namun dalam praktiknya, Peter (2009) memetakan dari kecenderungan hasil kajian partisipasi masyarakat secara politik cenderung bias pada kelompok berpendapatan tinggi dan pendidikan tinggi. Padahal democracy implies that citizens should participate on equal terms (Dahl, 1953 in Peter, 2009). Secara pada forum participatory public budgeting ditemukan bias kesempatan active citizen pada kelompo pemilik excessive power (Hong, 2015). Masyarakat praktisi dan akademisi menjembatani gap antara teori dan praktik ini untuk menerima ketidaksetaraan (inequalities) yang berakar dari struktur sosial ini, dan mereka tetap menerapkan prosedur demokrasi bahkan dengan keterbatasan ini. Penerimaan ini membawa konsekuensi paradok pada elemen inklusivitas representasi partisipan pada forum konsultasi publik, dikarenakan adanya anggapan bahwa active citizen berpotensi dimobilisasi. Sebaliknya, para pemimpin (leaders) dianggap sebagai penegndali proses dalam posisi relatif egaliter untuk mendistribusikan resources. Pendekatan governance mengembangkan komunitas partisipatif citizen active dengan membangun kapasitas sipil untuk menaikkan minat (demand) mereka terlibat dalam tata kelola pemerintahan oleh pemerintah. Pada saat yang sama, sengaja atau tidak, dapat terjadi juga pemupukan etos penundukan dan rasa sungkan atau kebanggaan dari warga karena dilibatkan dalam kekuasaan, sehingga terjadi etos klientilisme (Cox, 2009).

Konsep akuntabilitas sosial yang menekankan peran active citizen untuk menguatkan akuntabiltas publik berasumsi bahwa kelompok masyarakat bertindak dan berpihak pada kelompok masyarakat yang diwakilinya sehingga dapat mencegah pencurian sumber daya publik untuk kelompok elite. Fakta lapangan menunjukkan bahwa kelompok masyarakat pun cenderung berperilaku oportunistis dan bertindak tidak akuntabel (Yang and Callahan, 2005 dan Falaschetti, 2009). Inilah paradoks masyarakat sipil berpotensi menimbulkan paradoks active citizen - clientilsm.

Gejala paradok partisipasi masyarakat aktif dengan klientilisme pasif ini dijumpai dalam kasus forum konsultasi publik untuk penganggaran daerah partisipatif di Kota Surakarta dan kota Magelang, Provinsi 
Jawa Tengah, Indonesia. Penjelasan resiko patologis yang muncul antara pemerintah dengan active citizen dalam proses pengangaran patisipatif di lokasi penelitian ini dijelaskan oleh teori keagenan dari perspektif institusional.

Institusi terbentuk di sekitar keagenan dan mengalami perubahan dalam berurusan dengan agensi sebagai respons atas relasi yang secara esensial tidak sempurna dan tidak selalu sesuai sebagaimana yang diinginkan oleh pihak yang terkait. Masyarakat kemudian membentuk institusi-institusi untuk mengelola dan beradaptasi dan bisa jadi terdistorsi akibat dari ketidaksempurnaan itu (Mitnick, 2006). Teori keagenan menjelaskan bahwa relasi principal-agent berpotensi menciptakan moral hazard dan perilaku oportunistis yang merupakan penyimpangan normatif. Moral hazard adalah permasalahan yang muncul jika agen tidak melaksanakan hal-hal yang telah disepakati dengan principal (normatifnya). Perilaku oportunistis adalah memanfaatkan sumber daya dan akses yang dimiliki untuk kepentingan pribadi atau golongannya sendiri (self-interest).
Penggunaan teori keagenan sektor publik merujuk pada pendapat Lane (2003) yang mengatakan bahwa negara demokratis modern didasarkan pada suatu susunan hubungan principal-agent dalam sektor publik. Politisi sebagai agen, pemerintah sebagai agen, dan rakyat pemilih sebagai principal. Perwakilan warga juga dapat menjadi agen dalam hubungannya ketika ia mewakili kelompok warga lainnya. Asumsi dasar tentang problem relasi antara accountor dan accountee yang digunakan dalam teori keagenan, yaitu self interest dan perilaku oportunistis, digunakan untuk menjelaskan bentuk-bentuk patologi yang muncul dalam mekanisme konsultasi publik dalam proses penganggaran daerah ini.

Penyimpangan peran active citizen semakin dikondisikan pada lingkungan Prismatic Society (masyarakat prismatis) dengan sebagai birokrasi model Sala (Riggs, 1998). Salah satu cirinya adalah formalisme, yaitu adanya ketidaksesuaian dalam kadar yang cukup tinggi antara berbagai hal yang telah ditetapkan secara formal dengan praktik atau tindakan nyata di lapangan. Hal inilah salah satu penyebab paradok active citizen dengan 
klientilisme pada forum konsutasi publik yang didesain dalam format demokratis.

\section{Pembahasan}

Penelitian peran active citizen dalam forum konsultasi publik di kota Magelang dan Kota Surakarta, Provinsi Jawa Tengah, Indonesia ini menggunakan metode kualitatif, Strategi yang digunakan adalah studi kasus dengan fokus fenomenologis, yaitu hendak mengungkap hal-hal yang bersifat patologis dari rangkaian proses mekanisme konsultasi publik perencanaan penganggaran daerah. Penelitian ini menggunakan paradigma konstruktivisme dalam perspektif interpretif, yaitu menganalisis fenomena perilaku aktor dan cara pandangnya dalam praktik mekanisme proses konsultasi publik untuk perencanaan penganggaran di Kota Surakarta dan Kota Magelang, untuk menemukan hal-hal kontekstual yang menyebabkan perilaku aktor bias dari teori normatif peran active citizen. Jenis studi kasus yang diambil adalah studi kasus kolektif, yaitu meneliti bentuk-bentuk kasus yang memenuhi unsur penerapan mekanisme forum konsultasi publik dalam rangkaian proses perencanaan dan penganggaran daerah di Kota Surakarta dan Kota Magelang.

Konsultasi publik di Kota Surakarta maupun Kota Magelang terindikasikan adanya gejala dominasi elite. Meskipun secara normatif ada undangan terbuka, pada praktiknya panitia telah menentukan pihak yang akan menjadi pesertanya. Perwakilan yang dipilih cenderung bias elite, yaitu kelompok yang dekat dengan pengaruh kekuasaan, contoh: ketua $\mathrm{RT} / \mathrm{RW}$, tokoh masyarakat pengurus lembaga kemasyarakatan, kader partai, dan aktivis yang sering bersuara 'vokal'(dan menjadi target untukditundukkan pemerintah), dan organisasi yang tercatat secara formal di registrasi pemerintah kota. Secara normatif konsuktasi publik diformulasikan sebagai forum warga, tetapi masih ditemukan sikap kebanggaan pada aktivis yang dilibatkan sebagai bagian dari kekuasaan. Hal ini berakibat timbulnya rasa sungkan bagi perwakilan active citizen ini menyuarakan opini yang berbeda dengan mayoritas agenda pemerintah.

Dari aspek dinamika forum, terindikasi gejala patologi kooptasi forum yang memperkuat gejala klientilisme pada 
pengambilan keputusan yang prematur. Berdalih supaya forum lebih efisien dan efektif, maka mekanisme partisipasi dalam forum diatur oleh pemegang kekuasaan/birokrasi. Di dalam forum tidak terjadi proses dialog menjawab rasionalitas di balik pengambilan keputusan. Yang terjadi adalah membangun konsensus antara agenda pemerintah dnegan perwakilan active citizen dalam nuansa forum yang terkooptasi.

Di balik peran forum active citizen, ditemukan hal-hal yang menandakan adanya gejala oportunisme warga sipil yang menyuburkan pertumbuhan klientilisme. Sebagai contoh, kasus konflik Konsorsium Solo, Kompip (Konsorsium Monitoring Pemberdayaan Institusi Publik), dan Sompis (Solidaritas Masyarakat Pinggiran Surakarta) karena berebut sumber daya dana dan akses eksistensi pribadi yang diperoleh dari lembaga donor. Kepatuhan aktivis warga bergeser dari idealisme panguatan otonomi warga ke arah penguatan eksistensi diri dengan melekat pada pemilik kekuasaan (uang taupun kedudukan sosial).

Insentif uang transportasi kehadiran di forum warga sebagai pengganti opportunity cost sangat dominan. Informan lapangan mengatakan bahwa ada perpindahan profesi dari pedagang menjadi aktivis rapat. Semakin banyak LSM yang melakukan pendampingan penguatan forum warga maka akan semakin besar insentif uang yang diterima. Hal ini menumbuhkan ketergantungan dan klinetilisme warga sipil pada pihak yang sering membayarnya untuk terlibat dalam forum warga.

Perkembangan forum active citizen yang sering terlibat dalam forum konsultasi publik dengan berbagai latar belakangnya memiliki sisi baik, yaitu memunculkan kesadaran warga bahwa berorganisasi dalam forum warga itu meningkatkan daya tawar dalam rangka memperjuangkan nasib mereka. Namun, sisi gelapnya adalah elite forum warga ini cenderung terjebak melalukan komodifikasi forum, karena memiliki daya tawar di depan pemerintah karena memiliki massa yang dapat digerakkan. Potensi patologi yang muncul adalah makelar kebijakan dalam transaksi pasar gelap, dan cenderung memperkuat klientilisme pemegang kekuasaan. Sebagai contoh, dari kasus konsultasi publik proses penataan Pedagang Kaki Lima (Vendor Street) di kota Surakarta 
maupun Kota Magelang, muncul fenomena, pemimpin kelompok forum cenderung mendapatkan keuntungan fasilitas lebih dari pemerintah, berupa lokasi lebih strategis dan lebih banyak dibanding anggota pasif lainnya, atau mendapatkan tambahan proyek dari pemerintah.

Hasil penelitian juga mengidentifikasi adanya kelompok aktivis (active citizen) yang berperan sebagai perantara perdamaian jika ada kasus antara kelompok warga tertentu dengan pemerintah. Informasi dari pemerintah aupun dari aktivis warga, baik di kota Surakarta maupun kota Magelang, mengonfirmasi bahwa ada kelompok warga aktif yang digunakan pemerintah untuk menekan kelompok warga aktif yang lain supaya tidak membahayakan stabilitas kebijakan pemerintah. Modus yang digunakan ada, aktivis warga yang menjadi klientilis penguasa ini menawarkan solusi penyelesaian masalah di ruang isolasi diantara mereka sehingga tidak terbuka kepada publik lebih luas.

Pola umum yang ditarik dari penelitian kasus jamak (multi cases) di Kota Surakarta dan Kota Magelang ini menunjukkan adanya kecenderungan aktivis masyarakat (active citizen) cenderung terkooptasi pada lingkar kekuasaan yang mengokohkan hubungan klientilisme-patronage, yang dibangun dalam mekanisme partisipasi konsultasi publik. Hal ini menunjukkan paradok demokrasi, dimana mekanisme partisipatif yang seharusnya menguatkan otonomi dan independensi aktivis warga untuk mengontrol kekuasaan, justru melanggengkan hubungan dominasi kekuasaan.

\section{Penutup}

Kesimpulan, klientilisme active citizen di ruang konsultasi publik muncul karena efek paradoks demokrasi dalam konteks Sala birokarsi. Konteks Sala birokrasi menimbulkan ekses perilaku birokrat dan DPRD mengutamakan patron-klien sebagai partisipan forum konsultasi publik. Paradoks demokrasi muncul dari elemen representasi, partisipasi, inklusi, dan akuntabilitas, yang kemudian melahirkan persoalan berikut. (1) Siapa mewakili siapa, (2) menyuarakan kepentingan siapa, dan (3) bagaimana transparansi proses negosiasinya.

Dalam lingkungan demikian active citizen memanfaatkan forum untuk memperoleh 
keuntungan ekonomi maupun non ekonomi bagi dirinya. Sementara itu, pemegang kekuasaan juga memanfaatkan kehadiran, suara dan eccesive power yang mereka miliki untuk memuluskan agenda setting pemegang kekuasaan. Di sini terjadi paradoks active citizen dalam forum konsultasi publik. Mekanisme proses dalam format demokratis, tetapi mencerminkan hasil yang sesungguhnya berlawanan dengan nilai demokrasi.

Penelitian ini menemukan bahwa kualitas demokrasi dan kualitas birokrasi berimbas pada kualitas forum konsultasi publik. Jika tataran kualitas demokrasi berorientasi prosedural, serta birokrasi mengandung cacat kolusi dan nepotisme, maka forum konsultasi publik juga akan cacat dengan kooptasi dan komodifikasi forum, yang mengukuhkan relasi patron - klien. Hasilnya adalah konsultasi publik dan active citizen semu (pseudo active citizen dan pseudo public consultation forum).

Kerangka munculnya patologi diringkaskan berikut:

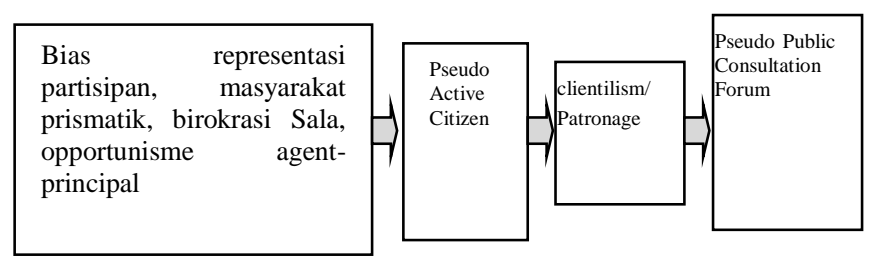

Figure 1.The Cause - Effect Active Citizen

- Klientilism/Petronage Paradox, Source:

Daa Analysis (2015)

Berdasar hasil penelitian di kota Surakarta dan kota Magelang ini, The next chalenging for further study is diperlukannza penelitian fundamental bagaimana menggeser wacana forum konsultasi publik adalah forum akuntabilitas untuk memenuhi kebutuhan klien ke arah bagaimana meningkatkan kualitas forum konsultasi publik sebagai ruang otonomi warga melakukan monitoring dan kontrol. Dengan kata lain, bagiamana menggeser wacana akuntabilitas berbasis responsibilitas (accountability as responsibility) ke arah akuntabilitas berbasis kompetensi keterbukaan menjawab preferensi nilai kepublikan warga (accountability as answerability). Pada ranah praktis, diperlukan kajian lanjutan tentang bagaimana mengurangi resiko paradok; dan pengembangan model insentif yang menciptakan kondisi partisipasi aktif yang berkelanjutan bagi smeua warga masyarakat secara inklusif. 


\section{Daftar Pustaka}

Clarke, M., \& Missingham, B. (2009). Active Citizenship and Social Accountability. Development in Practice, 19(8), 955-963, http://www.jstor.org/stable/27752162.

Fung, A. (2006). Varieties of Participation in Complex Governance. Special issue, Public Administration Review 66: 6675

Cox, J. (2009). Active citizenship or passive clientelism? Accountability and development in Solomon Islands. Development in Practice, 19:8, 964980.

Hong, S. (2015). Citizen Participation in Budgeting: A Tradeoff Between Knowledge and Inclusiveness. Public Administration Review, forthcoming. John, P. (2009). Can Citizen Governance Redress the Representative Bias of Political Participation? Public Administration Review, 69: 494-503.

Falaschetti, D. (2009). Democratic Governance and Economic Performance. New York: Springer.

Lane, J.E. (2003). Management and Public Organization: The Principal-Agent Framework, Working paper. University of Geneva and National University of Singapore.
Malena, C., Forster, R., Singh, J. (2004). Social Accountability: An Introduction to Concept and Emerging Practice. Social Development Papers, Participation and Public Engagement, Paper No. 76 December 2004.

Mitnick, B. M. (2013). Origin of the Theory of Agency: An Account By One of the Theory's Originators. http://dx.doi.org/10.2139/ssrn.1020378. Riggs, F.W. (1988). Administrasi Negaranegara Berkembang: Teori Masyarakat Prismatis. Taranslated by Tim Yosogama, Jakarta: Rajawali Press.

Yang, K. and K. Callahan, 2007, Citizen Involvement Efforts and Bureaucratic Responsiveness: Participatory Values, Stakeholder Pressures, and Administrative Practicality. Public Administration Review, 67(2), 249-264. 
Spirit Publik Volume 12, Nomor 2, Oktober 2018

Halaman 32-42

P-ISSN. 1907-0489 E-ISSN 2580-3875 